\title{
Quick and simple LC-MS/MS method for the determination of simvastatin in human plasma: application to pharmacokinetics and bioequivalence studies
}

\author{
Suéllen Cristina Rennó Silva1, Gustavo Rodrigues de Rezende ${ }^{2}$, Vanessa Bergamin Boralli ${ }^{1, *}$
}

${ }^{1}$ Laboratório de Análises de Toxicantes e Fármacos, Departamento de Análises Clínicas e Toxicológicas, Faculdade de Farmácia, Universidade Federal de Alfenas Alfenas, MG, Brazil, ${ }^{2}$ Centro de Pesquisa em Biotecnologia Ltda, Belo Horizonte, MG, Brazil

\begin{abstract}
A simple, rapid, and sensitive method based on liquid chromatography-tandem mass spectrometry for the quantitative determination of simvastatin in human plasma was developed and validated. After a simple extraction with methyl tert-butyl ether, the analyte and internal standard (lovastatin) were analyzed using reverse-phase liquid chromatography, on a Kinetex $\mathrm{C}_{18}$ column $(100 \times 4.6 \mathrm{~mm}, 2.6 \mu \mathrm{m}) \mathrm{using}$ acetonitrile: ammonium acetate $(2 \mathrm{mM}+0.025 \%$ formic acid $)(70: 30, \mathrm{v} / \mathrm{v})$ as a mobile phase in a run time of $3.5 \mathrm{~min}$. Detection was carried out using electrospray positive ionization mass spectrometry in the multiple-reaction monitoring mode. The method was linear over $0.04-40.0 \mathrm{ng} / \mathrm{mL}$ concentration range. The mean extraction recovery of simvastatin was $82 \%$ (RSD within $15 \%$ ). Intraday and interday precisions (as relative standard deviation) were all $\leq 8,7 \%$ with accuracy (as relative error) of $\pm 8 \%$. This rapid and reliable method was successfully applied for a bioequivalence study of $40 \mathrm{mg}$ of simvastatin orally disintegrating tablets in 44 healthy volunteers, showing that this method is suitable for the quantification of simvastatin in human plasma samples for pharmacokinetics and bioequivalence studies.
\end{abstract}

Uniterms: Simvastatin/determination. Liquid chromatography/quantitative analysis. Tandem mass spectrometry/quantitative analysis. Human plasma/determination of simvastatin. Simvastatin/ bioequivalence. Simvastatin/pharmacokinetics.

Desenvolveu-e e validou-se um método simples, rápido e sensível baseado na cromatografia líquida acoplada à espectrometria de massas em tandem para a quantificação de sinvastatina em plasma humano. Após um simples preparo de amostras utilizando extração com éter metil-terc-butílico, o analito e seu padrão interno (lovastatina) foram analisados por cromatografia líquida de fase reversa, em uma coluna Kinetex $\mathrm{C}_{18}(100 \mathrm{~mm} \times 4,6 \mathrm{~mm}$ x 2,6 $\mu \mathrm{m})$, utilizando uma fase móvel composta de acetonitrila:acetato de amônio ( $2 \mathrm{mM}+0,025 \%$ ácido fórmico) $(70: 30, \mathrm{v} / \mathrm{v})$ em tempo total de corrida de 3,5 min. A detecção foi realizada por espectrometria de massas utilizando a ionização por electrospray no modo positivo e monitorando os íons pelo sistema de monitoramento de reação múltipla. O método apresentou linearidade na faixa de $0,4-40,0 \mathrm{ng} / \mathrm{mL}$. A recuperação média obtida para sinvastatina foi de $82 \%$ (DPR menor que $15 \%$ ). A precisão intradia e interdias (como desvio padrão relativo) foi $\leq 8,7 \%$ com exatidão (como erro relativo) de $\pm 8 \%$. Este método rápido e confiável foi aplicado com sucesso em um estudo de bioequivalência de comprimidos de desintegração oral de sinvastatina $40 \mathrm{mg}$ em voluntários sadios, mostrando que este método é adequado para a quantificação de sinvastatina em plasma humano para estudos farmacocinéticos e bioequivalência.

Unitermos: Sinvastatina/determinação. Cromatografia líquida/análise quantitativa. Espectrometria de massas em tandem/análise quantitativa. Plasma humano/determinação de sinvastatina. Sinvastatina/ bioequivalência. Sinvastatina/farmacocinética.

\footnotetext{
*Correspondence: V. B. Boralli. Laboratório de Análises de Toxicantes e Fármacos, Departamento de Análises Clínicas e Toxicológicas, Faculdade de Farmácia, Universidade Federal de Alfenas. Rua Gabriel Monteiro da Silva, 700, 37130-000 -Alfenas - MG, Brasil. E-mail: vanessa.marques@unifal-mg.edu.br
} 


\section{INTRODUCTION}

Simvastatin is a cholesterol-lowering agent (Hoffman et al., 1986) and acts as a 3-hydroxy-3-methylglutarylcoenzyme A (HMG-CoA) reductase inhibitor effective in the treatment of hypercholesterolemia. It is an inactive hydrophobic lactone prodrug, which is metabolized in vivo to several more polar, pharmacologically active, compounds, most notably the corresponding hydroxy acid form, simvastatin acid (Mauro, 1993).

After an oral dose, the concentration of simvastatin in plasma is very low, probably because of high first-pass hepatic extraction resulting in low oral bioavailability (5\%) (Mauro, 1993; Vickers et al., 1990). Therefore, sensitive and selective methods for the determination of simvastatin in plasma have been required for therapeutic drug level monitoring.

Several methods for simvastatin determination in plasma have been reported, including gas chromatographymass spectrometry (GC-MS) (Takano, Abe, Hata, 1990), liquid chromatography coupled to UV detector (LC-UV) (Carlucci et al., 1992), and liquid chromatography coupled to fluorescence detector (LC-fluorescence) (Ochiai et al., 1997). However, GC-MS and LC-fluorescence methods include analyte derivatization with a generally complicated sample preparation procedure; LC-UV methods are not sensitive enough for measuring drug levels in plasma at therapeutic dose.

UPLC-MS/MS (ultra-performance liquid chromatography tandem mass-spectrometry) has numerous advantages, for example, very selective separations, comparatively short analysis times, and simple preliminary treatment of the sample.

The present paper reported an original UPLC-MS/ MS method for the quantification of simvastatin in human plasma, requiring a simple sample treatment using onestep extraction with a run time of only $3.5 \mathrm{~min}$ for each sample. This method exhibited excellent performance in terms of recovery, precision, accuracy, matrix effect, and low detectability (LLOQ of $0.4 \mathrm{ng} / \mathrm{mL}$ ). The suitability of this UPLC-MS/MS method for routine bioanalysis was proven by its application in sample quantification of clinical bioequivalence trials of two branded simvastatin tablets.

\section{MATERIAL AND METHODS}

\section{Chemicals and reagents}

Simvastatin USP reference standard (lot no. I1H070) and the internal standard (lovastatin, lot no. H4K027) were purchased from United States Pharmacopeia (Rockville, USA); the reference formulation was simvastatin tablet (each tablet containing $40 \mathrm{mg}$ of simvastatin) provided by Merck Sharp \& Dohme Ltd. (Northumberland, UK), and the test formulation was simvastatin tablet $(40 \mathrm{mg})$ provided by a Brazilian company (protected name by contractual confidentiality). Ammonium acetate, acetonitrile, and methyl tert-butyl ether (MTBE) were HPLC grade purchased from J.T. Baker (Phillipsburg, NJ, USA). Formic acid was from Sigma-Aldrich ${ }^{\mathrm{TM}}$ (St. Louis, Missouri, USA), and ammonium hydroxide was from Vetec ${ }^{\mathrm{TM}}$ (Rio de Janeiro, RJ, Brazil). Deionized water was prepared through the Milli-Q Plus Ultra-Pure water system (Millipore Corporation, Bedford, MA, USA). Heparinized blank (drug-free) human plasma was obtained from CEBIO clinic step, Belo Horizonte hospital (Belo Horizonte, MG, Brazil).

\section{Instrumentation}

The UPLC-MS/MS system consisted of a Waters Acquity UPLC ${ }^{\mathrm{TM}} \mathrm{H}-\mathrm{Class}$ system coupled to a triple quadrupole TQD ${ }^{\mathrm{TM}}$ mass spectrometer (Waters, Milford, MA, USA), which is equipped with electrospray ionization (ESI) source for ion production. Data acquisition and integration were controlled by MassLynx ${ }^{\mathrm{TM}}$ software (Version 4.1, Waters).

\section{LC-MS/MS conditions}

The chromatographic separation was performed on a Kinetex $\mathrm{C}_{18}$ column $(100 \times 4.6 \mathrm{~mm}$ I.D., $2.6 \mu \mathrm{m}$, Phenomenex, Torrance, CA, USA) maintained at $45^{\circ} \mathrm{C}$. The mobile phase consists of a mixture of acetonitrile: ammonium acetate $(2 \mathrm{mM}+0.025 \%$ formic acid $)(70: 30$, $\mathrm{v} / \mathrm{v}$ ) at a flow rate of $1.0 \mathrm{~mL} / \mathrm{min}$. The column effluent was split so that approximately $0.2 \mathrm{~mL} / \mathrm{min}$ entered the mass spectrometer, and the injection volume via autosampler (set as $5^{\circ} \mathrm{C}$ ) was $20 \mu \mathrm{L}$. The ESI source was operated on the positive ionization mode using multiple-reaction monitoring (MRM) of transitions of the protonated molecular ions. These transitions $(\mathrm{m} / \mathrm{z})$ with associated cone voltage $(\mathrm{V})$ and collision energies $(\mathrm{eV})$ were as follows: simvastatin 419.3>199.0, 22, 10, and lovastatin 405.0 $>199.0,18,14$. For simvastatin and lovastatin (IS), the source parameters maintained were desolvation gas flow (nitrogen): $550 \mathrm{~L} / \mathrm{h}$, cone gas flow (nitrogen): $50 \mathrm{~L} / \mathrm{h}$, capillarity voltage: $3.8 \mathrm{kV}$, source temperature: $140{ }^{\circ} \mathrm{C}$, desolvation temperature: $450{ }^{\circ} \mathrm{C}$, extractor $3.0 \mathrm{~V}$. Dwell time set was $0.15 \mathrm{~s}$ for both analytes. 


\section{Preparation of standard and quality control (QC) samples}

A stock solution ( $1 \mathrm{mg} / \mathrm{mL})$ of simvastatin was diluted with acetonitrile: water $(50: 50, \mathrm{v} / \mathrm{v})$ to produce standard solutions with concentrations of $4,10,25,50$, $100,150,250$, and $400 \mathrm{ng} / \mathrm{mL}$. Quality control (QC) solutions were prepared independently at low, medium, and high concentrations $(12,120$, and $300 \mathrm{ng} / \mathrm{mL})$ in the same way. A 50- $\mu \mathrm{L}$ aliquot of each standard solution was mixed with $450 \mu \mathrm{L}$ of pooled blank plasma (obtained from healthy human volunteers) to produce calibration standards of simvastatin with concentrations of $0.4,1$, $2.5,5,10,15,25$, and $40 \mathrm{ng} / \mathrm{mL}$. QC samples $(1.2,12$, and $30 \mathrm{ng} / \mathrm{mL}$ ) were generated from QC solutions with the same procedure. A stock solution $(1 \mathrm{mg} / \mathrm{mL})$ of lovastatin (IS) was prepared with acetonitrile: water $(50: 50, \mathrm{v} / \mathrm{v})$ and diluted in acetonitrile to give a final concentration of $0.15 \mu \mathrm{g} / \mathrm{mL}$. The solutions were stored at $5{ }^{\circ} \mathrm{C}$, and the plasma samples were stored in a $-20^{\circ} \mathrm{C}$ freezer.

\section{Sample preparation}

Plasma samples $(500 \mu \mathrm{L})$ were placed into $2.0 \mathrm{~mL}$ Eppendorf tubes. After adding $50 \mu \mathrm{L}$ of IS, the sample extraction was followed by adding $50 \mu \mathrm{L}$ of $50 \mathrm{mM}$ ammonium acetate buffer ( $\mathrm{pH} 4.5$ ) and extracted with $1000 \mu \mathrm{L}$ of methyl tert-butyl ether (MTBE) for $5 \mathrm{~min}$. After centrifugation at $5000 \mathrm{~g} / 5^{\circ} \mathrm{C}$ for $5 \mathrm{~min}, 850 \mu \mathrm{L}$ of the organic phase was transferred to another tube and evaporated to dryness under a gentle stream of air at room temperature. The residues obtained were reconstituted in $200-\mu \mathrm{L}$ aliquots of mobile phase and $20 \mu \mathrm{L}$ injected into the UPLC-MS/MS system.

\section{Method validation}

Method validation was performed according to ANVISA Guide for analytical and bioanalytical method validation (ANVISA, 2003) and according to FDA Guidance for Industry, Bioanalytical Method Validation (US Food and Drug Administration, 2001). Selectivity was assessed by comparing chromatograms of spiked plasma samples in the lower limit of quantification (LLOQ) concentration with plasmas from six different individuals. Linearity, in the range of $0.4-40 \mathrm{ng} / \mathrm{mL}$, was evaluated using the assay of three independent analytical curves on 3 different days by weighted linear regression $\left(1 / \mathrm{x}^{2}\right)$ of analyte/IS peak area ratios. Lower limit of quantification (LLOQ) was defined as the lowest concentration of analyte that could be quantitatively determined with precision of $\leq 20 \%$ and accuracy of $80-120 \%$ (ANVISA, 2003; Food and Drug Administration, 2001). Accuracy (as relative error - RE) and precision (as relative standard deviation RSD) were determined by assay of seven replicates of low, medium, and high QC samples on 3 different days. The intraday and interday precisions were required to be lower than $15 \%$ and the accuracy to be within $\pm 15 \%$, except at LLOQ, where it should not exceed 20\% (ANVISA, 2003; Food and Drug Administration, 2001). Recovery was determined by comparing the mean peak areas for five replicate analysis of low, medium, and high QC samples with those of blank plasma extracts reconstituted with the corresponding QC solutions. Recovery of the analyte need not be $100 \%$, but the extent of recovery of an analyte and the internal standard should be consistent, precise, and reproducible (ANVISA, 2003; Food and Drug Administration, 2001). Matrix effects can be described as the difference between the mass spectrometric response for an analyte in standard solution and the response for the same analyte in a biological matrix, such as plasma (Kebarle, Tang, 1993). Matrix effects were carried out by monitoring the instrument response of a constantly infused analytes after injecting an extract from an extracted blank sample into the UPLC-MS/MS system. This approach identifies chromatographic regions where an analyte would be most susceptible to suppression or enhancement. The stability of analytes was evaluated under all the storage conditions at two QC concentrations (low and high). The tested samples were compared with freshly prepared samples in five replicates. The long-term stability was assessed after storage of QC samples at $-20^{\circ} \mathrm{C}$ for 90 days. For the short-term stability, QC samples were kept at room temperature for $19 \mathrm{~h}$. The freeze/thaw stability test was performed after three complete freeze/ thaw cycles $\left(-20^{\circ} \mathrm{C}\right.$ to room temperature). Stability of processed samples was assessed by injection of extracted QC samples after conservation for $73 \mathrm{~h}$ at $5^{\circ} \mathrm{C}$. The stock solutions of simvastatin and lovastatin stored at $5{ }^{\circ} \mathrm{C}$ were compared with freshly prepared solutions after 60 days, and the same procedure was done to the solutions stored at room temperature for $18 \mathrm{~h}$.

\section{Pharmacokinetic study}

A randomized, single-dose, two-period, twosequence, and crossover design was used for the bioequivalence assessment of two branded simvastatin tablets, approved by the Research Ethic Committee of Belo Horizonte hospital, accredited by CONEP National Commission on Ethics Research (from Brazil). The bioequivalence study was followed by a washout 
period of one week. In each study period, volunteers were required to fast for approximately $8 \mathrm{~h}$ before the dosing. The formulations were administered with $200 \mathrm{~mL}$ water. Water and food were not allowed until $4 \mathrm{~h}$ after administration. Standardized meals were provided after 4 , 7, and $11 \mathrm{~h}$ of blood sampling. A total of forty-four male and female volunteers (age $18-40$ years; body mass index $18.5-27.0 \mathrm{~kg} / \mathrm{m}^{2}$ ) were considered to be in good health based on their medical history, physical examination, and routine laboratory tests. All volunteers read the protocol and gave written informed consent before entering the study. They were instructed to abstain from using any medications for at least one week before and during the study and from smoking and taking alcohol, caffeine, and xanthenes at least $48 \mathrm{~h}$ before administering the study drugs and throughout the study. Blood samples were collected into heparinized tubes before administration and at $0.33,0.66,1,1.33,1.66,2,2.33,2.66,3,3.33,3.66,4$, $6,8,10,12$, and $24 \mathrm{~h}$ post-dose ( $40 \mathrm{mg}$ simvastatin tablet). Plasma was separated immediately by centrifugation at $1800 \mathrm{~g}$ for $15 \mathrm{~min}$ and stored at $-20^{\circ} \mathrm{C}$ before analysis. The analytical batch consisted of blank, blank with internal standard (zero), eight calibration standards, and volunteer plasma samples involved in the study with QC samples interspersed (low, medium, and high concentrations).

\section{RESULTS AND DISCUSSION}

\section{LC-MS/MS conditions}

The ion mass spectra of each analyte are shown in Figure 1. The spectra were similar to those shown in previous reports for simvastatin and lovastatin (Apostolou et al., 2008; Nováková et al., 2009). The most abundant product ion of each analyte was selected for MRM monitoring. In both analytes, protonated molecule $[\mathrm{M}+\mathrm{H}]^{+}$was monitored in electrospray positive ionization mode. Therefore, the ion transitions $\mathrm{m} / \mathrm{z}$ 419.3>199.0 and 405.0>199.0 were selected for MRM of the simvastatin and the IS, respectively. Argon was used as collision gas, and collision energy was optimized for each analyte.

UPLC was used as separation method for the analysis of simvastatin and lovastatin. The chromatographic conditions were investigated on several different reversed phase columns (BEH $\mathrm{C}_{18}$, Symmetry $\mathrm{C}_{18}$, Kinetex $\mathrm{C}_{18}$ ) to obtain a suitable retention time and symmetrical peak shape. To get the shortest analysis time and avoid the matrix effects, different percentages of acetonitrile were tested. In early experiments, acetonitrile: ammonium acetate $(2 \mathrm{mM}+25 \%$ formic acid $)(85: 15, \mathrm{v} / \mathrm{v})$ was applied as mobile phase, but when it was changed for acetonitrile: ammonium acetate $(2 \mathrm{mM}+0,025 \%$ formic acid) $(70: 30, \mathrm{v} / \mathrm{v})$, the signal achieved the maximum response and had better peak shapes. On the other hand, these changes greatly increased the running time. This mobile phase was deemed unacceptable for practical routine use. Therefore, to reduce the running time, the mobile phase flow was increased to $1.0 \mathrm{~mL} / \mathrm{min}$ with a split ratio of 1: 4 (MS/MS:waste). This last condition allowed a running time of $3.5 \mathrm{~min}$ with enough simvastatin area response at LLOQ concentration.

The best combinations of peak shape and retention time were achieved using Kinetex $\mathrm{C}_{18}$ column (100 mm $\mathrm{x} 4.6 \mathrm{~mm}, 2.6 \mu \mathrm{m})$ using acetonitrile: ammonium acetate $(2 \mathrm{mM}+0,025 \%$ formic acid) $(70: 30, \mathrm{v} / \mathrm{v})$ as a mobile phase, which was operated isocratically in $1.0 \mathrm{~mL} / \mathrm{min}$ at a column temperature of $45^{\circ} \mathrm{C}$.

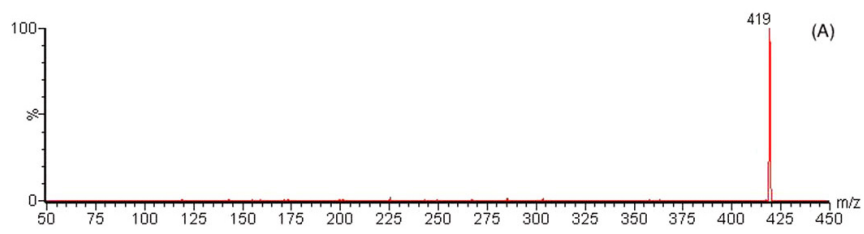

(B)
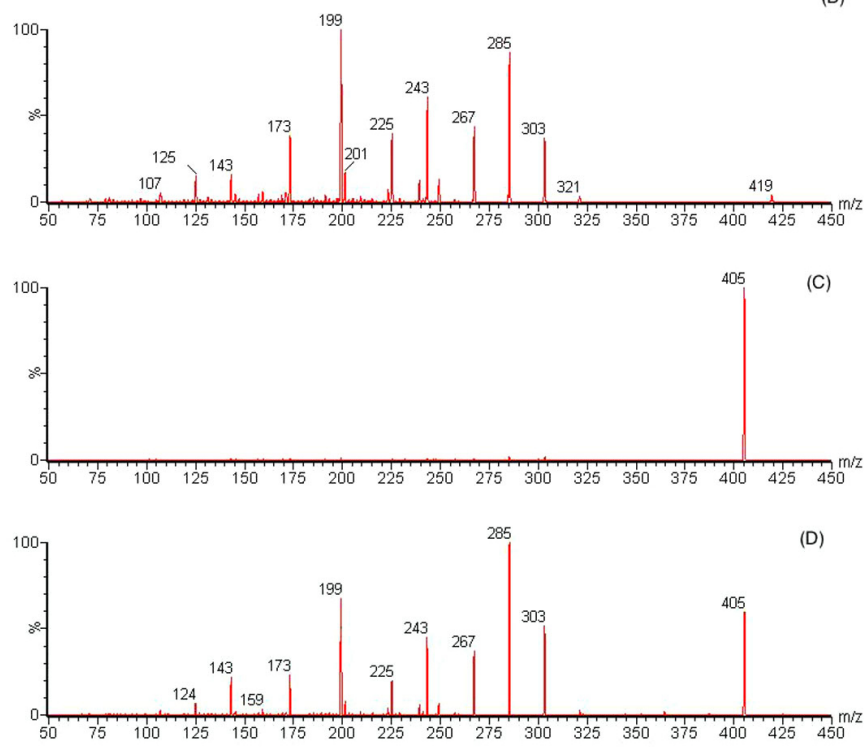

FIGURE 1 - Ion mass spectra $[\mathrm{M}+\mathrm{H}]^{+}$: (A) simvastatin precursor ion, (B) simvastatin product ion, (C) lovastatin precursor ion, and (D) lovastatin product ion.

\section{Sample preparation}

Different methods of sample preparation including solid-phase extraction (SPE), protein precipitation, and liquid-liquid extraction (LLE) with various organic solvents (such as ethyl acetate, hexane, dichloromethane, 
chloroform, and methyl tert-butyl ether) were evaluated. SPE required lengthy extraction procedure when compared with a simple LLE. Protein precipitation introduces serious matrix effects. Besides, a dirty extract may damage the equipment during bioanalytical routine. LLE using MTBE had numerous advantages, for example, very simple sample preparation, clean extracts, high extraction efficiency, and fast organic solvent evaporation. The addition of ammonium acetate buffer $(\mathrm{pH} 4.5)$ to plasma before extraction enhanced the recovery of simvastatin and IS. It could also help in displacing drug from protein and to prevent interconversion between simvastatin and simvastatin acid, at the same time maintaining the acidic analytes in a nonionic lipophilic form. Consistent and reproducible recoveries were obtained using MTBE as an extraction solvent in comparison with the other tested ones.

\section{Assay validation}

\section{Selectivity}

There was no significant interference from endogenous substances in human plasma at the analytes retention time window. Figure 2 shows typical MRM chromatograms of blank human plasma and a plasma sample spiked at the LLOQ $(0.4 \mathrm{ng} / \mathrm{mL})$ concentration in both ion transitions determined $(\mathrm{m} / z$ 419.3>199.0 and 405.0>199.0). The chromatograms show excellent peak shape for both the analyte and IS, and the retention times were short enough to allow a run time of $3.5 \mathrm{~min}$, which is suitable for routine analysis. The areas observed at the retention time windows of simvastatin and lovastatin were less than $20 \%$ of their LLOQ area $(\mathrm{m} / z$ 419.3 $>199.0)$, and it was less than 5\% IS area, as observed in the LLOQ sample $(\mathrm{m} / \mathrm{z} 405.0>199.0)$.
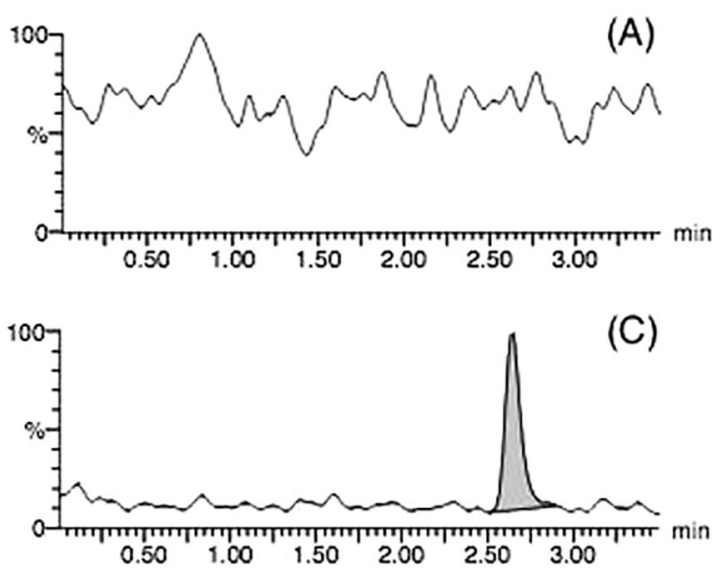

\section{Linearity and sensitivity}

The eight-point calibration curve obtained using weighted linear regression $\left(1 / \mathrm{x}^{2}\right)$ showed good linearity over the whole concentration range $(0.4-40 \mathrm{ng} / \mathrm{mL})$, which covered the concentrations found in human plasma after administration of simvastatin in this pharmacokinetic study. The correlation coefficient was better than 0.99 , and a typical equation of calibration curve was $y=0.121288 x$ -0.0000502624 . The least-squares linear regression was used to mathematically define the calibration line. A weighting factor $\left(1 / \mathrm{x}^{2}\right)$ was used to avoid bias at the calibration line in favor of the high standards. This was especially important because a wide calibration range was selected. The LLOQ (defined as the lowest concentration that could be analyzed with acceptable accuracy and precision (20\%) was $0.4 \mathrm{ng} / \mathrm{mL}$ with a mean accuracy of $103.3 \%$ and a mean precision of $12.3 \%(n=7)$.

\section{Accuracy and precision}

The assay procedure proved to be precise and accurate. The intraday $(\mathrm{n}=7)$ and the interday precision ( $n=3$ days, seven replicates per day) showed results lower than $15 \%$ RSD, for the three QC concentrations. The intraday and the interday accuracy, expressed as a percentage of nominal values, showed values within $\pm 15 \%$, for all three QC concentrations (Table I).

\section{Recovery and matrix effects}

The most important parameter affecting the simvastatin recovery is the $\mathrm{pH}$ value used in the extraction. The extraction conditions were evaluated to achieve maximum extraction efficiency for both analytes and, at the same time, minimum interconversion between
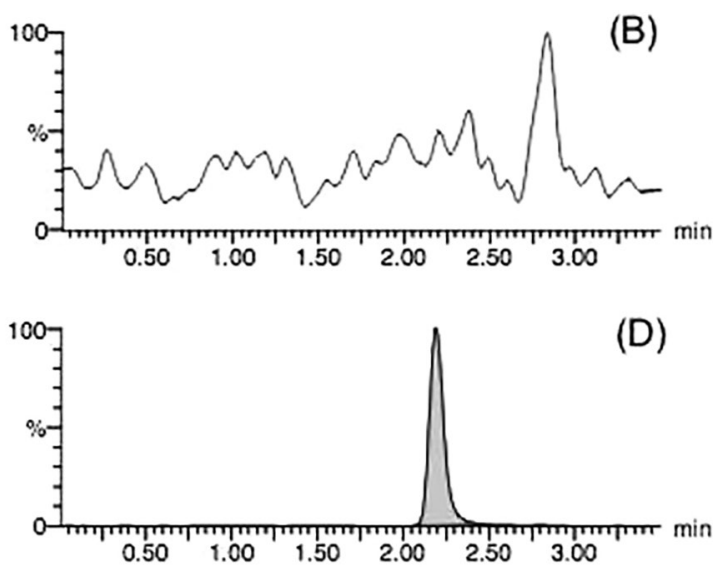

FIGURE 2 - Blank human plasma chromatograms $m / z$ 419.3>199.0 (A); 405.0>199.0 (B) and a plasma sample spiked at the LLOQ (0.4 ng/mL) concentration $\mathrm{m} / z$ 419.3>199.0 (C); 405.0>199.0 (D). 
TABLE I - Precision and accuracy for simvastatin in human plasma

\begin{tabular}{lccccccccc}
\hline Spiked concentration (ng/mL) & \multicolumn{3}{c}{$\mathbf{1 . 2} \mathbf{~ n g / m L}$} & \multicolumn{3}{c}{$\mathbf{1 2 . 0} \mathbf{~ n g} / \mathbf{m L}$} & \multicolumn{3}{c}{$\mathbf{3 0 . 0} \mathbf{~ n g} / \mathbf{m L}$} \\
\hline Mean concentration intraday (ng/mL) & 1.2 & 1.3 & 1.1 & 13.0 & 12.5 & 11.6 & 31.3 & 30.1 & 28.0 \\
Precision intraday (RSD\%) & 6.1 & 6.3 & 4.5 & 4.7 & 6.2 & 8.7 & 7.3 & 5.3 & 6.0 \\
Mean accuracy intraday (\%) & 103.5 & 104.9 & 94.2 & 108.1 & 104.0 & 97.0 & 104.4 & 100.3 & 93.3 \\
Mean concentration interday (ng/mL) & & 1.2 & & & 12.3 & & & 29.6 \\
Precision interday (RSD\%) & & 7.3 & & & 7.9 & & 7.5 \\
Mean accuracy interday (\%) & \multicolumn{3}{c}{100.6} & & & & & & \\
\end{tabular}

RSD: relative standard deviation; Intraday assays: $n=7$; Interday assays: $n=3$

TABLE II - Extraction recovery of simvastatin and lovastatin

\begin{tabular}{lcccc}
\hline Spiked concentration & $\begin{array}{c}\text { Simvastatin } \\
\mathbf{1 . 2} \mathbf{~ n g} / \mathbf{m L}\end{array}$ & $\begin{array}{c}\text { Simvastatin } \\
\mathbf{1 2 . 0} \mathbf{~ n g} / \mathbf{m L}\end{array}$ & $\begin{array}{c}\text { Simvastatin } \\
\mathbf{3 0 . 0} \mathbf{~ n g} / \mathbf{m L}\end{array}$ & $\begin{array}{c}\text { Lovastatin } \\
\mathbf{0 . 1 5} \boldsymbol{\mu g} / \mathbf{m L}\end{array}$ \\
\hline RSD (\%) & 12.7 & 12.4 & 1.4 & 10.6 \\
Recovery (\%) & 93.0 & 79.1 & 76.4 & 82.1 \\
\hline
\end{tabular}

RSD: relative standard deviation $(n=5)$

lactone and acid form. The optimum $\mathrm{pH}$ for the extraction buffer was between 4 and 5 . Any $\mathrm{pH}>5$ would produce lower extraction efficiency. A pH of 4.5 was chosen after evaluation of three $\mathrm{pH}$ values between 4 and 5 .

The samples were purified using a simple process of liquid - liquid extraction (LLE) using MTBE as extractor solvent, which allowed good recovery for simvastatin and lovastatin compared with other tested solvents. As shown in Table II, the mean extraction recoveries measured from the LLE extraction procedure were approximately $80 \%$ for both drugs.

The postcolumn infusion method was enough in matrix effects determination. As shown in Figure 3, there was no ion suppression or ion enhancement at the chromatographic retention times of both analytes. This

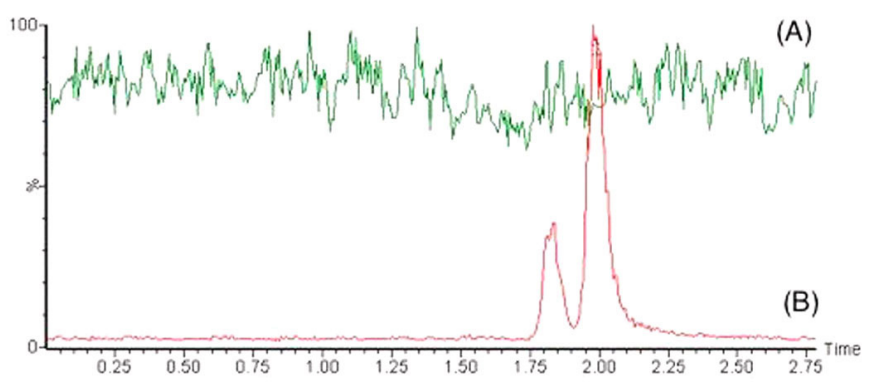

FIGURE 3 - Instrument response from constantly infused analytes after injecting an extracted blank sample into the UPLC-MS/MS system (A); UPLC-MS/MS injection of both analytes in mobile phase solution, not concomitant, just for comparison (B). technique allows one to intelligently modify the elution time of an analyte so that it does not fall into suppression/ enhancement zones.

The evaluation of possible matrix effects is an essential part of method development/validation for any LC-MS-MS method. If relevant matrix effects are found, they should be reduced or eliminated by the optimization of chromatographic conditions, improving the sample cleanup and/or by changing the type of ionization employed. Typically, suppression or enhancement of analyte response is accompanied by diminished precision and accuracy of subsequent measurements. Thus, matrix effects can limit the utility of LC-MS/MS for quantitative analysis.

\section{Stability}

Stability results in Table III demonstrate that simvastatin is stable with deviation $<15 \%$ under the indicated conditions for the pharmacokinetic study.

The stock solutions of simvastatin and lovastatin stored at $5{ }^{\circ} \mathrm{C}$ per 60 days and at room temperature $/ 18 \mathrm{~h}$ were compared with fresh solutions and were considered stable at those conditions.

The stability of the analytes in human plasma, at storage conditions, were evaluated over a period equal to the typical sample preparations, sample handlings, and analytical run times.

\section{Pharmacokinetic study}

The validated UPLC-MS/MS method was success- 
TABLE III - Stability of simvastatin in human plasma under various conditions $(\mathrm{n}=5)$

\begin{tabular}{lcccc}
\hline Storage conditions & $\begin{array}{c}\text { Added concentration } \\
(\mathbf{n g} / \mathbf{m L})\end{array}$ & $\begin{array}{c}\text { Freshly sample } \\
(\mathbf{n g} / \mathbf{m L})\end{array}$ & $\begin{array}{c}\text { Stored sample } \\
(\mathbf{n g} / \mathbf{m L})\end{array}$ & RE (\%) \\
\hline human plasma for 90 days & 1.2 & 1.1 & 1.1 & -3.3 \\
at $\mathbf{- 2 0} \mathbf{~}^{\mathbf{C}}$ & 30.0 & 30.2 & 28.5 & -5.5 \\
human plasma at room & 1.2 & 1.1 & 1.1 & 1.8 \\
temperature for 19 $\mathbf{h}$ & 30.0 & 28.3 & 28.3 & -0.0 \\
human plasma after three & 1.2 & 1.1 & 1.1 & -5.3 \\
freeze/thaw cycles & 30.0 & 28.3 & 32,3 & 14.2 \\
processed samples at $\mathbf{5}^{\circ} \mathbf{C}$ & 1.2 & 1.3 & 1.3 & 4.3 \\
for $\mathbf{7 3}$ h & 30.0 & 27.8 & 31.8 & 14.3 \\
\hline
\end{tabular}

RE: relative error $(n=5)$

fully applied to a bioequivalence study in healthy human volunteers who received 40-mg tablet of simvastatin reference and test formulations under fasting conditions.

The samples were processed based on the proposed quick and simple extraction procedure for the quantification of simvastatin in human plasma. The method was sensitive enough to monitor the simvastatin plasma level concentration up to $24 \mathrm{~h}$ after oral dose.

The basic pharmacokinetics parameters $\left(\mathrm{C}_{\max }\right.$, $\mathrm{AUC}_{0-\mathrm{t}}, \mathrm{AUC}_{0-\infty}, \mathrm{t}_{\text {max }}$, and $\mathrm{t}_{1 / 2}$ ) obtained for test and reference drugs in healthy subjects in this bioequivalence study were summarized in Table IV. The mean plasma concentration-time profile of healthy human volunteers, after single oral dose administration of reference and test products of $40 \mathrm{mg}$ simvastatin tablets is shown in Figure 4.

After natural logarithmic transformation using general linear model procedure to evaluate the effects of sequence, period, and formulation, at significance level $(\alpha)$ of 0.05 , no statistically significant effect of sequence was found, showing that the washout period was enough to not cause carryover effects. However, the period effect and formulation effect were statistically significant with

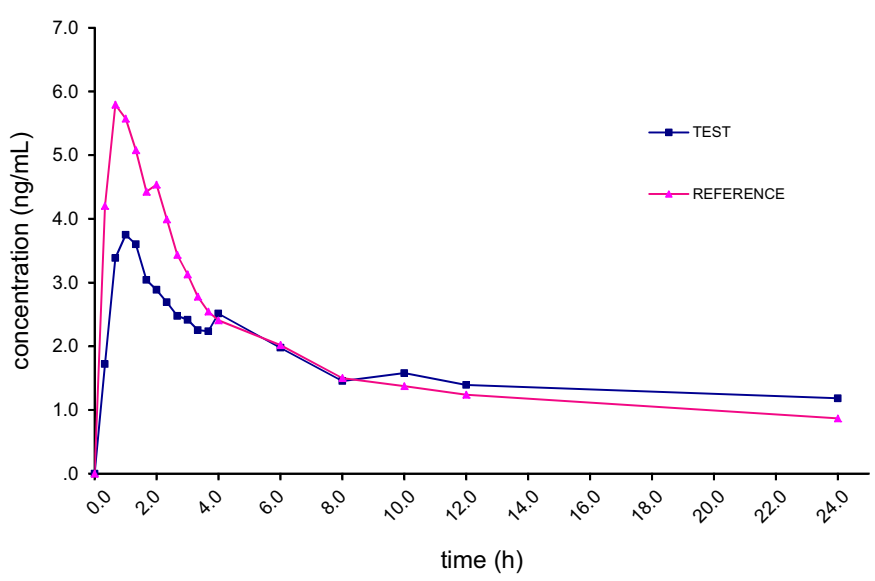

FIGURE 4 - Mean plasma concentration-time profile of healthy volunteers, after single oral dose administration of reference and test products of simvastatin tablets.

results of 0.0091 for $\mathrm{C}_{\max }$ (period effect); $<0.0001$ for $\mathrm{C}_{\max }$, and 0.0276 for $\mathrm{AUC}_{0-\infty}$ (formulation effect). These results can suggest that there was some variability between test and reference formulations.

These findings do not confirm the bioequivalence

TABLE IV - Pharmacokinetic parameters for test and reference drugs in healthy subjects in bioequivalence study

\begin{tabular}{|c|c|c|c|}
\hline Parameters & $\begin{array}{c}\text { Reference formulation (mean } \\
\pm \text { S.D.) }\end{array}$ & $\begin{array}{l}\text { Test formulation } \\
(\text { mean } \pm \text { S.D.) }\end{array}$ & $\begin{array}{l}90 \% \text { Confidence } \\
\text { interval }(\%)\end{array}$ \\
\hline $\mathrm{C}_{\max }(\mathrm{ng} / \mathrm{mL})$ & $9.0 \pm 5.1$ & $5.8 \pm 3.7$ & $55,9-72,7$ \\
\hline $\mathrm{AUC}_{0-\mathrm{t}}(\mathrm{h} . \mathbf{n g} / \mathrm{mL})$ & $35.5 \pm 18.7$ & $36.1 \pm 19.5$ & $88,8-112,6$ \\
\hline $\mathrm{AUC}_{0-\infty}(\mathrm{h} . \mathrm{ng} / \mathrm{mL})$ & $50.4 \pm 41.3$ & $68.8 \pm 79.3$ & $106,4-150,2$ \\
\hline $\mathbf{t}_{\max }(\mathbf{h})$ & $1.4 \pm 1.2$ & $2.3 \pm 2.7$ & - \\
\hline $\mathbf{t}_{1 / 2}(\mathrm{~h})$ & $10.5 \pm 12.6$ & $18.0 \pm 21.4$ & - \\
\hline$\underline{\mathbf{K}_{\mathrm{el}}}$ & $0.1 \pm 0.1$ & $0.1 \pm 0.1$ & - \\
\hline
\end{tabular}

$\mathrm{C}_{\max }$ : peak concentration; $\mathrm{AUC}_{0-\mathrm{t}}$ area under the plasma concentration time curve from zero to the last nonzero concentration time; $\mathrm{AUC}_{0-\infty}$ : area under the curve from zero to infinity; $\mathrm{t}_{\max }$ : time to peak concentration; $\mathrm{t}_{1 / 2}$ : half-life; $\mathrm{K}_{\mathrm{el}}$ : elimination rate constant; S.D.: standard deviation 
between $40 \mathrm{mg}$ test sample and the reference product in terms of rate and extent of absorption.

\section{CONCLUSIONS}

A quick, simple, selective, precise, and accurate UPLC-MS/MS method was developed and validated for the quantification of simvastatin in human plasma. The main advantages of this method were as follows: simple and fast sample preparation (one-step extraction), excellent recovery, minor matrix effects, low chromatographic run time (only $3.5 \mathrm{~min}$ for each sample), and low detectability (LLOQ of $0.4 \mathrm{ng} / \mathrm{mL}$ ). The method was shown to be adequate and reliable for application to pharmacokinetics and bioequivalence studies of simvastatin.

\section{ACKNOWLEDGMENTS}

The authors would like to acknowledge CEBIO (Centro de Pesquisa em Biotecnologia, Belo Horizonte, Brazil) for financial support and CAPES (Coordenação de Aperfeiçoamento de Pessoal de Nível Superior, Brasília, Brazil) for granting research fellowships.

\section{REFERENCES}

AGÊNCIA Nacional de Vigilância Sanitária. Guia para validação de métodos analíticos e bioanalíticos. RE 899 . ANVISA, 2003.

APOStOlOU, C.; KOUSOUlOS, C.; DOTSIKAS, Y.; SOUMELAS, G-S.; KOLOCOURI, F.; ZIAKA, A.; LOUKAS, Y.L. An improved and fully validated LCMS/MS method for the simultaneous quantification of simvastatin and simvastatin acid in human plasma. $J$. Pharm. Biomed. Anal., v.46, n.4, p.771-779, 2008.

CARLUCCI, G.; MAZZEO, P.; BIORDI, L.; BOLOGNA, M. Simultaneous determination of simvastatin and its hydroxy acid form in human plasma by high-performance liquid chromatography with UV detection. J. Pharm. Biomed. Anal., v.10, n.9, p.693-697, 1992.

HOFFMAN, W.F.; ALBERTS, A.W.; ANDERSON, P.S.; CHEN, J.S.; SMITH, R.L.; WILLARD, A.K. 3-Hydroxy3-methylglutaryl-coenzyme A reductase inhibitors. 4. Sidechain ester derivatives of mevinolin. J. Med. Chem., v.29, n.5, p.849-852, 1986.
KEBARLE, P.; TANG, L. From ions in solution to ions in the gas phase - the mechanism of electrospray mass spectrometry. Anal. Chem., v.65, n.22, p.972A-986A, 1993.

MAURO, V.F. Clinical pharmacokinetics and practical applications of simvastatin. Clin. Pharmacokinet., v.24, n.3, p.195-202, 1993.

NOVÁKOVÁ, L.; VLCKOVÁ, H.; SATÍNSKY, D.; SADÍLEK, P.; SOLICHOVÁ, D.; BLÁHA, M.; BLÁHA, V.; SOLICH, P. Ultra high performance liquid chromatography tandem mass spectrometric detection in clinical analysis of simvastatin and atorvastatin. $J$. Chromatogr. B Analyt. Technol. Biomed. Life Sci., v.877, n.22, p.2093-2103, 2009.

OCHIAI, H.; UCHIYAMA, N.; IMAGAKI, K.; HATA, S.; KAMEI, T. Determination of simvastatin and its active metabolite in human plasma by column-switching highperformance liquid chromatography with fluorescence detection after derivatization with 1-bromoacetylpyrene. $J$. Chromatogr. B Biomed. Sci. Appl., v.694, n.1, p.211-217, 1997.

TAKANO, T.; ABE, S.; HATA, S. A selected ion monitoring method for quantifying simvastatin and its acid form in human plasma, using the ferroceneboronate derivative. Biomed. Environ. Mass Spectrom., v.19, n.9, p.577-581, 1990.

FOOD and Drug Administration. Guidance for industry, bioanalytical method validation. Centre for drug evaluation and research (CDER). Rockville: FDA, 2001. 22 p.

VICKERS, S.; DUNCAN, C.A.; CHEN, I.W.; ROSEGAY, A.; DUGGAN, D.E. Metabolic disposition studies on simvastatin, a cholesterol-lowering prodrug. Drug Metab. Dispos., v.18, n.2, p.138-145, 1990.

Received for publication on $03^{\text {rd }}$ July 2013 Accepted for publication on $25^{\text {th }}$ September 2013 